\title{
Editorial
}

\section{Tissue-Derived Stem Cell Research}

\author{
Ming Li, ${ }^{1}$ Kequan Guo, ${ }^{2}$ Dong Hyun Kim, ${ }^{3}$ and Luca Vanella ${ }^{4}$ \\ ${ }^{1}$ Department of Stem Cell Disorders, Kansai Medical University, Hirakata, Osaka 5731010, Japan \\ ${ }^{2}$ Department of Cardiac Surgery, Beijing Institute of Heart, Lung \& Blood Vessel Disease, Beijing Anzhen Hospital, \\ Capital Medical University, Beijing 100029, China \\ ${ }^{3}$ Northwest Ohio Orthopedics and Sports Medicine Inc., NWO Stem Cure, LLC, 7595 County Road 236, Findlay, OH, USA \\ ${ }^{4}$ Department of Drug Science, Section of Biochemistry, University of Catania, 95125 Catania, Italy \\ Correspondence should be addressed to Ming Li; liming@hirakata.kmu.ac.jp
}

Received 9 December 2015; Accepted 13 December 2015

Copyright ( $) 2016$ Ming Li et al. This is an open access article distributed under the Creative Commons Attribution License, which permits unrestricted use, distribution, and reproduction in any medium, provided the original work is properly cited.

Tissue-derived stem cells (TDSCs) are undifferentiated cells, presented in tissues such as bone marrow, blood vessels, and adipose tissues and with the ability to repair damaged areas by generation of new cells and tissues. TDSCs have proven to be a feasible source of cells for tissue regeneration medicine in recent experimental and clinical studies. Mesenchymal stem cells revealed potential benefits in atherosclerosis [1] and endothelial progenitor cells reduced lung damage and improved lung function [2]. Moreover, there were some reports that suggested that adipose derived stem cells may improve injured lung function [3], infracted heart function [4], and injured kidney and its function [5]. Regulation of the process to successfully trigger proper differentiation into the desired cell types is important. Moreover, it is more important to confirm safety of transplantation when stem cells are used to treat diseases.

In the present special issue, the significance and possible clinical applications of TDSCs were presented. Some manuscripts described important biochemical cascade underlying the processes of osteogenesis, adipogenesis, angiogenesis, and their possible applications in new therapy development. All findings and experiences of TDSCs research will open up new possibilities for the treatment of various diseases and extend the human life span.

\section{References}

[1] S. H. Abdel-Kawi and K. S. Hashem, "Possible therapeutic effect of stem cell in atherosclerosis in albino rats. A histological and immunohistochemical study," International Journal of Stem Cells, vol. 8, no. 2, pp. 200-208, 2015.

[2] A. Güldner, T. Maron-Gutierrez, S. C. Abreu et al., "Expanded endothelial progenitor cells mitigate lung injury in septic mice," Stem Cell Research \& Therapy, vol. 6, article 230, 2015.

[3] G. I. Aboul-Fotouh, M. B. Zickri, H. G. Metwally, I. R. Ibrahim, S. S. Kamar, and W. Sakr, "Therapeutic effect of adipose derived stem cells versus atorvastatin on amiodarone induced lung injury in male rat," International Journal of Stem Cells, vol. 8, no. 2, pp. 170-180, 2015.

[4] L. L. Bagno, D. Carvalho, F. Mesquita et al., "Sustained IGF-1 secretion by adipose-derived stem cell improves infarcted heart function," Cell Transplantation, 2015.

[5] W. Yao, Q. Hu, Y. Ma et al., "Human adipose-derived mesenchymal stem cells repair cisplatin-induced acute kidney injury through antiapoptotic pathways," Experimental and Therapeutic Medicine, vol. 10, no. 2, pp. 468-476, 2015.
Ming Li

Kequan Guo

Dong Hyun Kim

Luca Vanella 

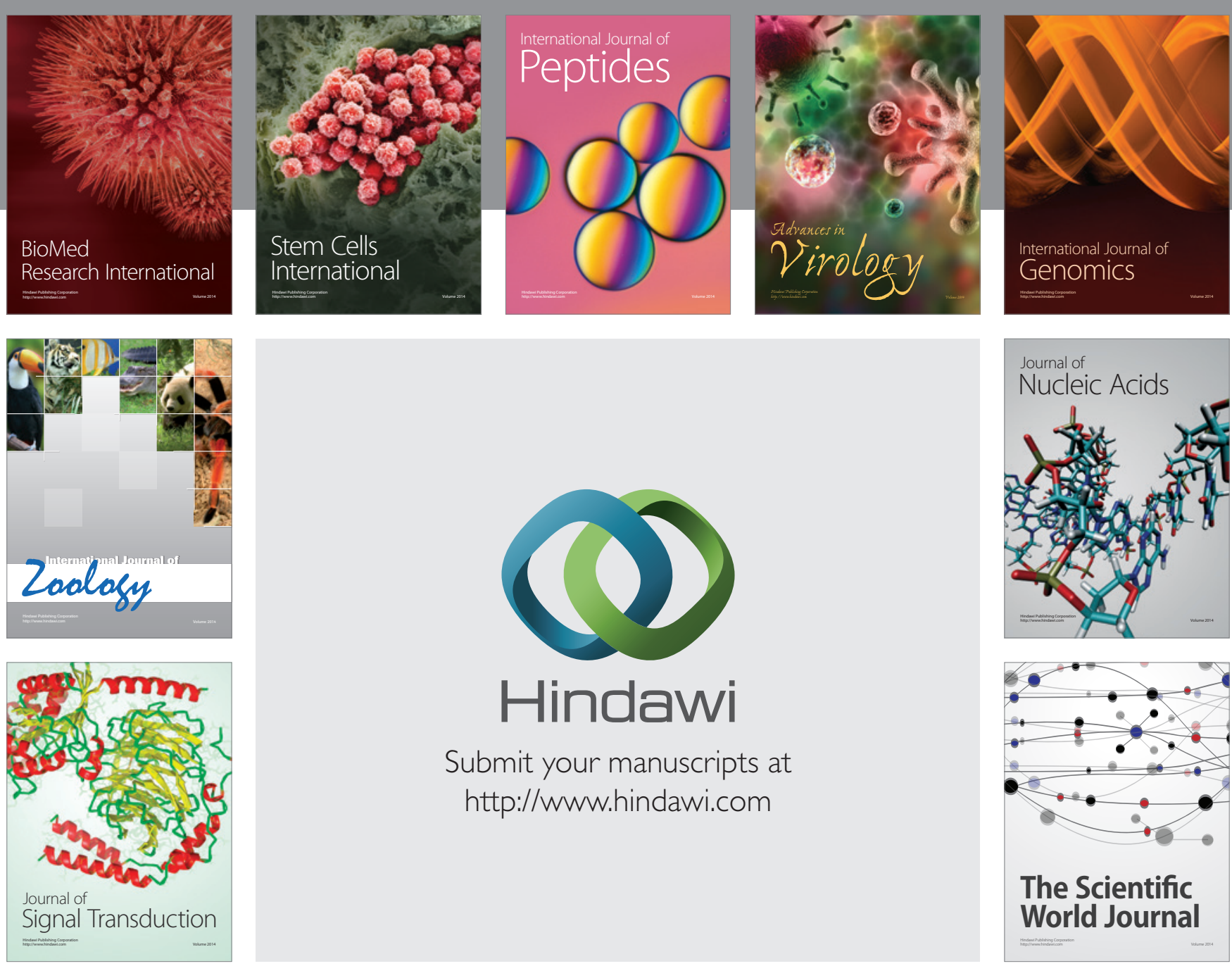

Submit your manuscripts at

http://www.hindawi.com
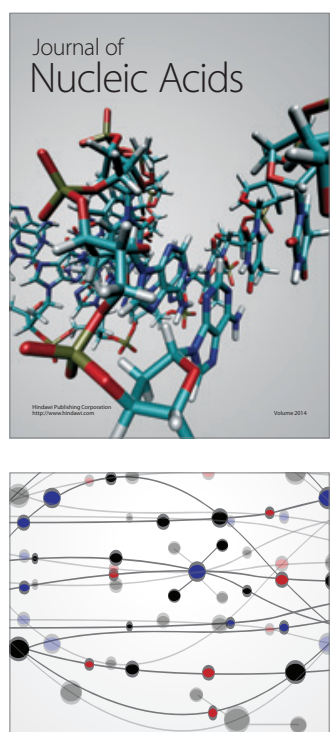

The Scientific World Journal
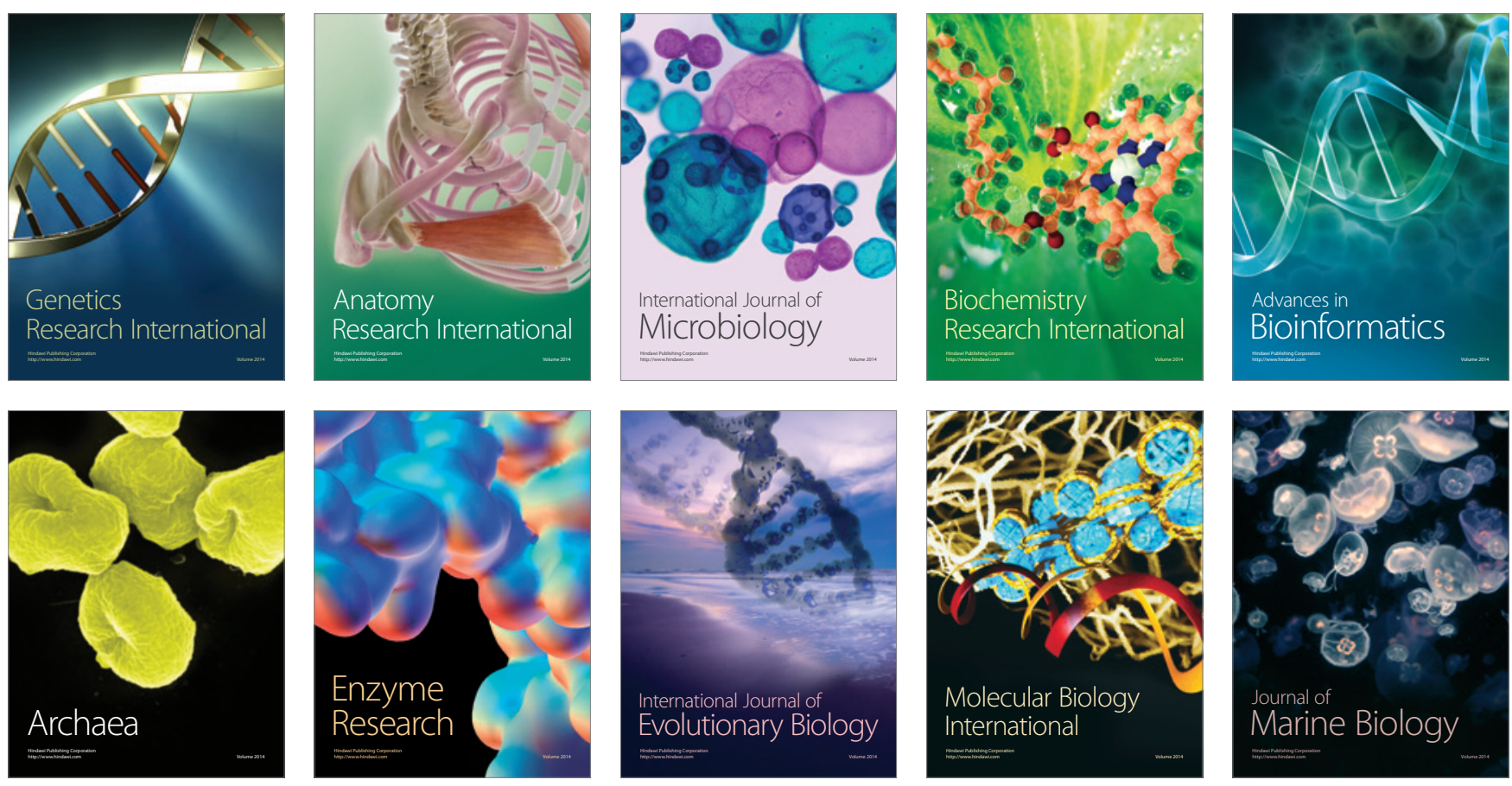